\title{
Konseling pengungkapan diri melalui puisi pelipur lara efektif mengurangi stres belajar mahasiswa
}

\author{
Akhmad Harum $\left.{ }^{1 *}\right)$ \& Kustiah Sunarty ${ }^{2}$ \\ Universitas Negeri Makassar ${ }^{12}$ \\ *) Alamat korespondensi: Jl. A.P. Pettarani, Makassar, 90222, Indonesia; E-mail: akhmad.harum@unm.ac.id
}

Article History: Received: 03/02/2021; Revised: $30 / 06 / 2021$ Accepted: 30/06/2021. Published: 30/06/2021.

How to cite: Harum, A. \& Sunarty, K. (2021) Konseling pengungkapan diri melalui puisi pelipur lara efektif mengurangi stres belajar

mahasiswa. Teraputik: Jurnal Bimbingan dan Konseling, 5(1), pp. 158-165. DOI: 10.26539/teraputik.51559

\begin{abstract}
Abstrak: Penelitian ini didasarkan pada stress yang dialami oleh mahasiswa sebagai akibat dari belajar yang tidak lepas dari beban psikologis yang dirasakan karena faktor belajar. Tujuan penelitian ini, yakni menjelaskan langkah-langkah konseling pengungkapan diri melalui puisi pelipur lara dan untuk menjabarkan hasil penurunan stress belajar mahasiswa melalui teknik konseling puisi pelipur lara. Metode penelitian menggunakan kuantitatif, quasi experimental dengan desain nonequlvalent pretest-postest group design. Hasil penelitian menunjukkan terdapat penurunan stress belajar mahasiswa, dilihat tingkat stress belajar pada saat pretes berada pada kategori tinggi dengan nilai rata-rata 99.40 dan pada saat posttest tingkat belajar berada pada kategori sedang dengan nilai rata-rata 71.00. Taraf signifikansi yang digunakan dalam uji Wilcoxon signed rank test sebesar $5 \%$ atau 0,05 , dengan nilai signifikan $(P)=$ Asymp $\operatorname{Sig}<a=0,05$ diperoleh nilaiZ yaitu $-2.810 b$ dengan nilai Asymp Sig 0,005 . Hal ini bermakna bahwa konseling pengungkapan diri melalui puisi pelipur larasecara singnifikan dapat mengurangi stress belajar mahasisiswa.
\end{abstract}

Kata Kunci: Stres Belajar, Pengungkapan Diri, Puisi

Abstract: This research is based on the stress experienced by students as a result of learning which cannot be separated from the psychological burden felt due to learning factors. The purpose of this study is to explain the steps of self-disclosure counseling through solace poetry and to describe the results of reducing student learning stress through solace poetry counseling techniques. The research method uses a quantitative, quasi-experimental design with a nonequilvalent pretest-posttest group design. The results showed that there was a decrease in student learning stress, seen the level of learning stress at the time of the pretest was in the high category with an average value of 99.40 and at the posttest the level of learning was in the medium category with an average value of 71.00. The level of significance used in the Wilcoxon signed rank test is $5 \%$ or 0.05 , with a significant value $(P)=$ Asymp Sig $<=0.05$, the $Z$ value is $2.810 \mathrm{~b}$ with an Asymp Sig value of 0.005 . This means that self-disclosure counseling through consolation poetry can significantly reduce student learning stress.

Keywords: Learning Stress, Self Disclosure, Poetry

\section{Pendahuluan}

Setiap orang pernah mengalami stres, baik ringan, sedang, maupun berat. Istilah "stres" sering digunakan secara tidak tepat, yakni dipakai untuk menunjuk fenomena "tidak waras". Sebenarnya, stres merupakan istilah yang netral, yakni menunjuk pada hal yang selalu dialami manusia dalam kehidupan sehari-hari. Secara sederhana, stres dapat didefinisikan sebagai suatu keadaan individu yang terganggu keseimbangannya. Stres terjadi akibat adanya situasi eksternal atau internal yang memunculkan gangguan dan menuntut individu untuk berespon adaptif (Smith, 1993).

Suatu hal yang harus diketahui bahwa tubuh manusia secara automatis sebenarnya dapat mengatasi stres yang sesekali terjadi, akan tetapi dalam situasi masyarakat sekarang yang penuh ketegangan, masalah dan konflik sering datang secara bergantian dan tidak memberikan waktu dan peluang kepada kita untuk mengelolanya. Apabila suatu gejolak atau permasalahan dibiarkan begitu saja dan tidak di temukan cara terbaik dalam menyelesaikannya, maka hal tersebut akan menjadi beban yang mengakibatkan individu mengalami stres. Hal ini sesuai dengan Hans Selye (1976) Stres merupakan suatu respons tubuh yang nonspesifik dari berbagai 
tuntutan. Tuntutan ini berdasarkan fenomena diatas dapat menyebabkan gejala stres yang dapat mengganggu kegiatan belajar mahasiswa. Stres menurut Lazarus dan Folkman (1984) diartikan sebagai reaksi psikis dan psikologis terhadap tuntutan hidup yang membebani kehidupan seseorang yang akan menganggu kesejahteraan hidupnya dan..

Stres yang terjadi di lingkungan kampus maupun sekolah disebut stres belajar, stres yang muncul sebagai akibat dari belajar tidak lepas dari beban psikologis yang dirasakan karena faktor belajar. Aktivitas belajar mahasiswa dapat berupa kegiatan belajar-mengajar didalam kelas maupun diluar kelas, ujian-ujian dan tugas-tugas yang diberikan oleh dosen. Dalam mengikuti kegiatan pembelajaran banyak tuntutan-tuntutan baru yang lebih ketat untuk dihadapinya. Hal ini berkaitan dengan kegagalan akademis atau tuntutan-tuntutan akademis lainnya (Lal, 2014; Sujadi, 2019). Terdapat beberapa faktor penyebab munculnya stres akademik, di antaranya: pertama, proses penyesuaian secara signifikan yang dilakukan mahasiswa dalam kehidupan kampus; kedua, tekanan studi dan konflik antar pribadi; dan ketiga, pengaturan tempat tinggal serta perubahan gaya hidup (Ross et al., 1999)

Tuntutan ini berupa tugas yang diberikan lebih banyak, tugas yang diberikan lebih sulit untuk dikerjakan, tuntutan terhadap materi yang harus dipelajari dari guru setiap mata pelajaran yang harus dipahami dengan cepat agar tidak tertinggal, adanya ulangan harian yang juga berpengaruh pada nilai akhir, mata pelajaran yang lebih sulit dari sebelumnya. Hal ini membuat mahasiswa stres dan dapat memperlihatkan perilaku yang tidak tepat, sehingga dapat menghambat proses belajar dan mengajar. Bentuk dan cara penyelesaian tugas itu juga beragam yaitu dapat berupa tugas berkelompok atau tugas mandiri, setiap tugas yang diberikan oleh guru bidang studi memiliki tingkat kesulitan masing-masing. Dalam proses menyelesaikan tugas yang terbatas oleh waktu tersebut mereka tentunya merasakan ketegangan sampai akhirnya mereka menyelesaikan tugas dan hal tersebut berdampak psikologis berupa, kecemasan, kegelisahan, berkeringat dingin, susah tidur, kurangnya konsentrasi, dan lain-lain. Mahasiswa dapat mengalami stres yang berat dan berkepanjangan

Berdasarkan dari studi lapangan diperoleh Stres yang dialami mahasiswa dapat dilihat dari gejala-gejala stres yang tampak pada mahasiswa. Gejala-gejala mahasiswa yang mengalami stres belajar, seperti: gelisah atau tegang saat akan diberikan tugas-tugas sekolah maupun tugas pekerjaan rumah, berkeringat dingin dan gemetar jika disuruh bertanya atau menjawab pertanyaan, enggan disuruh maju mengerjakan soal-soal dipapan tulis, dan gelisah bila menghadapi ujian semester. Gejala-gejala yang dialami mahasiswa tersebut berkaitan dengan aktivitas belajarnya. Kondisi tersebut jika tidak ditangani akan dapat berdampak terhadap rendahnya kemampuan belajar mahasiswa Seperti: gemetar pada saat disuruh maju mengerjakan soal-soal di papan tulis, dan gelisah bila menghadapi ujian semester. Gejala-gejala stres yang dialami mahasiswa tersebut berkaitan dengan aktivitas belajarnya

Terbebas dari stres akan membuat seseorang memiliki ketenangan jiwa sehingga dapat bertindak dengan lebih tertata dan mudah menimbang segala sesuatu yang terjadi dengan pikiran jernih. Dosen sekaligus konselor yang tergabung pada UPT LBK UNM pada perguruan tinggi memiliki tanggung jawab untuk menangani mahasiswa yang memiliki masalah, dalam hal ini konselor UPT LBK dapat membantu peserta didik dalam mengurangi stres mahasiswa menghadapi aktivitas belajar dengan menggunakan teknik konseling yang sesuai dengan permasalahan yang dialami mahasiswa sehingga mahasiswa mampu menghadapi seluruh kegiatan belajar tanpa adanya rasa cemas yang berlebihan yang dapat menimbulkan stres

Secara teoretik, stress belajar mahasiswa merupakan salah satu perilaku menyimpang yang sering dialami mahasiswa muncul dalam bentuk yang beraneka ragam. Mulai dari perilaku menyimpang karena kecemasan traumatik dan neurotik, ketidak bermaknaan hidup, masa depan yang tidak menentu, tidak bisa menentukan pilihan secara bertanggung jawab, kegagalan menakhoda diri sendiri, tidak bisa bertransaksi dengan orang lain, kegagala berpikir rasional, kegagalan kita menfilter stimulus dan kegagalan memberikan hadiah (reward) dan menghukum (punishment) diri sendiri, ketidakmampuan mengenali kepakaran diri sehingga mahasiswa kehilangan peluang untuk menata kehidupan sendiri. 
Berdasarkan dengan uraian di atas, Johnson (1981) menganggap bahwa pengungkapan diri sangatlah penting. Hal ini didasarkan pada pendapat yang mengatakan bahwa pengungkapan diri merupakan indikasi dari kesehatan mental seseorang. Anggapan tersebut didukung oleh temuan penelitian yang menunjukkan bahwa individu yang mampu mengungkapkan diri secara tepat terbukti lebih mampu menyesuaikan diri (adaptive), lebih percaya pada diri sendiri, lebih kompeten, lebih terbuka, lebih dapat diandalkan, lebih mampu bersikap positif dan percaya terhadap orang lain, dan lebih obyektif (Johnson, 1981). Selain itu, juga meyakini bahwa berbagi informasi dengan orang lain dapat meningkatkan kesehatan jiwa, mencegah penyakit dan mengurangi masalah-masalah psikologis yang menyangkut hubungan antarpribadi.

Dari segi komunikasi dan pemberian bantuan kepada orang lain, salah satu cara yang dianggap paling tepat dalam membantu orang lain untuk mengungkapkan diri adalah dengan mengungkapkan diri kepada orang tersebut terlebih dahulu. Tanpa keberanian untuk mengungkapkan diri maka orang lain akan bertindak yang sama, sehingga tidak tercapai komunikasi yang efektif. Pengungkapan diri dianggap paling penting dalam komunikasi antarpribadi karena sangat menentukan keberhasilan dalam pergaulan Orang yang bisa mengungkapkan diri tertarik kepada orang lain, percaya diri sendiri dan percaya pada orang lain. Selain itu, kemampuan mengungkapkan diri dapat meningkatkan kepercayaan, dan keakraban terhadap orang lain (Johnson, 1990; Gainau, 2005).

Pengungkapan diri bisa ditingkatkan dengan menggunakan teknik-teknik bantuan dalam profesi pemberian bantuan (Helping Profession), dalam hal ini bimbingan konseling. Salah satu teknik bantuan yang dapat kita gunakan untuk meningkatkan kemampuan mengungkapkan diri adalah menggunakan puisi. Dalam kesempatan ini digunakan istilah "Teknik Konseling Puisi Pelipur Lara" Dari perspektif bimbingan dan konseling puisi sebagai teknik konseling pelipur penting bagi setiap orang, melalui puisi mahasiswa akan dapat mengungkapkan perasaan secara positif yang selama ini sulit untuk diungkapkan. Hal ini sesuai Mahmud (2017) bahwa penggunaan puisi dalam bimbingan dan konseling dan psikoterapi dapat dilakukan dengan cara memberikan kesempatan kepada seseorang untuk mengungkapkan pikiran, perasaan, emosi dan masalah-masalah yang selama ini ditutup-tutupinya. Pengungkapan tersebut dapat dilakukan dalam bentuk non-verbal dan verbal. Cara non-verbal dilakukan dengan menuliskan ungkapan-ungkapan perasaan yang selama ini sulit diutarakan. Ungkapan-ungkapan perasaan tersebut dibuat dalam bentuk kata-kata perasaan yang sedang dialami pada saat itu, kemudian kata-kata tersebut dibuat menjadi serangkaian bait-bait puisi. Cara verbal dilakukan dengan mendeklamasikan puisi yang telah dibuat. Jika konseling puisi diimpelementasikan dalam konseling individual, maka klien mendeklamasikannya di hadapan konselor. Tetapi, jika puisi diterapkan dalam konseling kelompok, konseli mendeklamasikan puisinya di depan konseli yang lain sebagai anggota kelompok. Jika puisi diterapkan dalam teknik self-help, maka puisi dideklamasikan sendiri tanpa kehadiran orang lain sebagai pendengar. Penggunaan puisi dalam bimbingan konseling dan psikoterapi mengikuti prosedur (Rothenberg) (1) pembentukan kelompok (2) konselor mempresentasikan teknik, (3) latihan puisi, dan (4) mendeklamasikan puisi

Rumusalah masalah dalam penelitian ini: 1. Bagaimana langkah-langkah pelaksanaan konseling pengungkapan diri melalui puisi pelipur larauntuk mengurangi stress belajar mahasiswa? 2. Bagaimana penurunan stress belajar mahasiswa dengan diterapkannya teknik konseling puisi pelipur lara. Tujuan penelitian ini menjelaskan langkah-langkah pelaksanaan konseling pengungkapan diri melalui puisi pelipur larauntuk mengurangi stress belajar mahasiswa dan untuk menjabarkan hasil penurunan stress belajar mahasiswa melalui teknik konseling puisi pelipur lara.

Manfaat peneltian diharapkan dirasakan bagi mahasiswa, bagi Dosen, bagi universitas negeri Makassar dan bagi pengembangan ilmu pengetahuan. Bagi mahasiswa, penelitian ini bermanfaat mengurangi stress belajar. Bagi dosen, penelitian diharapkan mendapat kemudahan dalam menerapkan konseling pengungkapan diri melalui puisi pelipur larapada mahasiswa. Bagi ilmu pengetahuan, khususnya bidang bimbingan dan konseling, dapat menambah wawasan 
bahwa konseling pengungkapan diri melalui puisi pelipur laradapat mengurangi stress belajar mahasiswa.

Bertolak dari uraian di atas, peneliti merasa tertarik untuk melakukan suatu kajian (penilitian ilmiah) untuk menguji secara empirik Konseling Puis Pelipur Lara Untuk Mengurangi Stress Belajar Mahasiswa Universitas Negeri Makassar.

\section{Metode}

Penelitian ini adalah penelitian kuantitatif dengan jenis penelitian quasi experimentalyang akan mengkaji membandingkan tingkat stress belajar mahasiswa sebelum dan setelah diberikan model bimbingan kooperatif. Desain penelitian yang digunakan adalah "nonequlvalent pretestpostest group design.

Populasi penelitian ini adalah Mahasiswa Universitas Negeri Makassar sebanyak 120 yang terindikasi mengalami stress belajar. Teknik sampel yang digunakan adalah purposive sampling. Sampel penelitian sebanyak 20 mahasiswa yang teridentifikasi mengalami stress belajar sangat tinggi.

Penelitian diawali dengan studi literature, penyusunan rencana, instrument, pengujian instrument, revisi instrument, penyusunan panduan konseling, pelaksanaan, pengumupulan data, analisis data, penyusunan laporan, hingga penyusunan luaran artikel ilmiah. Penelitian ini dilakukan selama 5 bulan dimulai bulan Juli sampai dengan November 2018. Instrument yang dgunakan berupa skala stres belajar. Proses penyusunan skala ini dikembangkan berdasarkan teori stress dalam Hans Selye (1976), Lazarus dan Folkman (1984). Instrumen ini mengacu pada evaluasi proses dan hasil dari kegiatan untuk memastikan validitas instruen adalah pendekatan konstruk dan pendekatan untuk memastikan realibilitas instrumen adalah konsistensi internal. Teknik analisis data yang digunakan adalah statistik deskriptif dan Uji non parametric Wilcoxon Signed Rank Test (Z) dengan dasar pengujian (Asymp.Sig) > 0,05. Kegiatan penelitian ini berbasis konseling kelompok untuk membantu mahasiswa menurunkan stress belajar yang dialami. Pelaksanaannya dilakukan dengan tahapan kegiatan, yaitu: 1) Identifikasi stress belajr mahasiswa; 2) Identifikasi alasan perasaan stress belajar mahasiswa; 3) Menetapkan perasaan yang paling menggangu; 4) Mengidentifikasi harapan; 5) Menulis Puisi; 6) Deklamasi; 7) Mengukur tingkat stress belajar setelah pembacaan puisi; 8) Evaluasi diri; dan 9) Terminasi.

\section{Hasil dan Diskusi}

Hasil penelitian menjawab dua rumusan masalah, pertama pemaparan langkah-langkah pelaksanaan teknik konseling puisi pelipur lara. Kedua, pemaparan penurunan stress belajar mahasiswa setelah intervensi.

Berikut ini dijelaskan Gambaran Pelaksanaan Konseling Puisi Pelipur Lara Mengurangi Stress Belajar Mahasiswa di Universitas Negeri Makassar. Pelaksanaan konseling pelipur lara yang diberikan mulai dari pre-test sampai pada post-test berlangsung selama 8 kali pertemuan. Adapun rincian kegiatan sebagai berikut.

1. Identifikasi Stres Belajar Mahasiswa. Tahap ini konselor melakukan pengungkapan diri (selfdisclosure) dengan cara meminta konseli mengidentifikasi stress belajar yang dialaminya saat ini. Stress belajar ini berupa gejala fisik dan psikis yang ditimbulkan ketika mengalami stres belajar. Setelah konseli berhasil mengidentifikasi stress belajar yang yang dirasakannya, konselor dapat melanjutka wawancara konseli ketahap identifikasi alasan yang menyebabkan lahirnya perasaan stress tersebut.

2. Identifikasi alasan stress belajar mahasiswa. Tahap ini konselor melakukan pengungkapan diri dengan cara meminta klien menuliskan kembali kata-kata perasaan yang telah dikemukakan pada tahap satu, kemudian konselor mengarahkan konseli untuk menuliskan alasan -alasan yang mendorong lahirnya perasaan itu. Pada saat pelakanaan tahap ini mahasiswa mengungkapkan alasan stress karena tugas kuliah yang terlalu banyak dan dan sulit untuk diselesaikan. Setelah konseli berhasil mengidentifikasi alasan-alasan yang 
bersifat pribadi yang menyertai stress belajar yang dirasakannya, konselor dapat melanjutkan wawancara konseling ketahap menetapkan kegalauan yang paling mengganggu dan ingin diatasi.

3. Menetapkan perasaan yang paling mengganggu. Tahap ini konseli menetapkan stress belajar yang paling mengganggu perasaan konseli dan ingin segera diatasi dengan menggunakan teknik penyekalaan (scaling technique). Konselor menggunakan skala 0-5 atau 10-100." Setelah konseli berhasil menetapkan stress belajat yang paling mengganggu perasaannya dan ingin segera diatasi dengan menggunakan teknik penyekalaan (scaling technique). konselor dapat melanjutkan wawancara konseling ketahap mengidentifikasi harapan.

4. Mengidentifikasi harapan. Tahap ini konseli mengidentifikasi harapannya sebagai bentuk solusi dari kegalauan paling dirasakan saat ini. Dalam hal ini bisa saja konseli mengemukakakan lebih dari satu harapan. Setelah klien berhasil mengidentifikasi harapanharapan yang bersifat pribadi yang menyertai stres belajar yang dirasakannya, konselor dapat melanjutkan wawancara konseling ketahap latihan menulis puisi.

5. Menulis puisi. Tahap ini, konseli berlatih menuliskan kata-kata perasaan dan alasannya dalam bentuk serangkaian kata-kata berbentuk puisi yang berkaitan dengan stress belajar. Setelah konseli berhasil menulis puisi, konselor dapat melanjutkan prose konseling ketahap latihan membacakan atau mendeklamasikan puisi.

6. Deklamasi. Tahap ini konselor konseli mendeklamasikan atau membacakan puisi yang telah ditulisnya dengan suara yang nyaring dan mengekspresikan segenap perasaannya disertai gerakan tangan atau gerakan anggota tubuh lainnya. Pada pelaksanaan tahap ini konseli berlatih mengekspresikan stress belajar dengan membacakan puisi yang dibuat dengan memadukan berbagi ekspresi ketika membacakan sehingga memudahkan merefleksikan kedalam diri pribadi. Konseli merasa terwakilkan dari stress yang dialami saat ini sehingga mampu mengalihkan perhatian dengan aktivitas mendeklamasikan puisi. Setelah konseli mendeklamasikan puisinya di depan konselor dan konseli yang lain, konselor dapat melanjutkan proses konseling ke tahap mengukur tingkat kegalauan diri sendiri pasca pendeklamasian puisi.

7. Mengukur tingkat kegalauan setelah pembacaan puisi. Tahap ini konseli menilai sendiri tingkat kegalauannya setelah menulis dan membacakan puisinya dengan cara menggunakan teknik penyekalaan (scaling technique). Konselor menggunakan skala 0-5 atau 10-100." Setelah klien berhasil menetapkan tingkat kegalauannya sendiri pasca pembacaan puisi di hadapan konselor, konselor dapat melanjutkan proses konseling ke tahap evaluasi diri.

8. Evaluasi diri. Tahap ini evaluasi diri, konselor konseli menentukan tingkat perubahan atau penurunan perasaan stres belajar dengan cara membandingkan hasil penyekalaan sebelum penulisan dan pembacaan puisi dan hasil penyekalaan sesudah penulisan dan pembacaan puisi. Setelah konseli berhasil mengevaluasi dirinya sendiri, konselor dapat melanjutkan proses konseling ke tahap terminasi..

9. Terminasi. Tahap ini, klien membuat ringkasan sebagai hasil pertemuan, menentukan tingkat perubahan atau penurunan perasaan stress belajar dengan cara membandingkan hasil penyekalaan sebelum penulisan dan pembacaan puisi dan hasil penyekalaan sesudah pendeklamasian puisi.

Analisis statistik deskriptif dengan menggunakan wilxocom untuk memperoleh gambaran mengenai stress belajar mahasiswa sebelum (pretest) dan sesudah (posttest) diberi perlakuan berupa konseling puisi pelipur lara terhadap mahasiswa UNM dengan terlebih dahulu melakukan uji normalitas dan homogenitas. Berikut ini akan di sajikan dalam bentuk tebel distribusi frekuensi dan presentase, yang diklarifikasi atas kategori: sangat tinggi, Tinggi, Rendah dan Sangat Rendah. Lebih jelasnya dapat dilihat pada tabel berikut.

Tabel 1. Hasil Sebelum (Pretest) dan Sesudah (Posttest) Stress belajar mahasiswa UNM 


\begin{tabular}{cllrrrr}
\hline \multirow{2}{*}{ Interval } & \multirow{2}{*}{ Kategori } & \multicolumn{2}{c}{ Pretest } & \multicolumn{2}{c}{ Postest } \\
\cline { 2 - 6 } & & $\mathrm{F}$ & $\mathrm{P}(\%)$ & $\mathrm{F}$ & $\mathrm{P}(\%)$ \\
\hline $99-121$ & Sangat Tinggi & & 4 & $40 \%$ & - & - \\
\hline $76-98$ & Tinggi & & 6 & $60 \%$ & 2 & $20 \%$ \\
\hline $53-75$ & Rendah & - & - & 8 & $80 \%$ \\
\hline $30-52$ & Sangat Rendah & - & & - & - & \\
\hline & Jumlah & 10 & $100 \%$ & 10 & $100 \%$ \\
\hline
\end{tabular}

Sumber: Hasil skala stress belajar

Berdasarkan tabel diatas tampak bahwa dari 10 responden penilitian stress belajar mahasiswa pada saat pretest 4 orang atau 40\% pada kategori sangat tinggi dan 6 orang berada pada kategori tinggi atau $60 \%$. Setelah diberikan perlakuan berupa konseling pengungkapan diri melalui puisi pelipur laradiketahui bahwa stress belajar mahasiswa mengalami penurunan. Hal tersebut sesuai dengan hasil posttest, bahwa dari 10 orang responden yang di teliti ternyata 2 orang atau $20 \%$ berada pada kategori tinggi dan 8 orang atau $80 \%$ pada kategori rendah.

Tabel di atas sejalan Goldman, Cristin, Wong, \& Eugene, 1997), Stres belajar yang dialami mahasiswa berkaitan dengan, (1) tekanan akademik (bersumber dari guru, mata pelajaran, metode mengajar, strategi belajar, menghadapi ulangan/diskusi di kelas), dan (2) tekanan sosial (bersumber dari teman-teman sebaya siswa). Stres yang dialami siswa selanjutnya akan berpengaruh pada fisik dan aspek psikologisnya yang akan mengakibatkan terganggunya proses belajarnya.

Untuk mengetahui pengaruh konseling puisi pelipur lara yang digunakan untuk mengurangi stress belajar mahasiswa UNM maka digunakan uji hipotesis. Hipotesis penelitian ini adalah "Konseling Puisi Pelipur Lara dapat mengurangi Stres Belajar Mahasiswa UNM". Untuk memenuhi persyaratan uji analisis statistik maka hipotesis kerja $\left(\mathrm{H}_{1}\right)$ diubah kedalam hipotesis nol $\left(\mathrm{H}_{0}\right)$ sehingga berbunyi "Tidak terdapat perbedaan stress belajar mahasiswa UNM sebelum dan setelah pemberian perlakuan berupa konseling puisi pelipur lara". Untuk pengujian hipotesis di atas, terlebih dahulu disajikan data stress belajar mahasiswa UNM.

Tabel 2. Hasil Pengujian Hipotesis Penelitian Menggunakan SPSS 20 For Windows

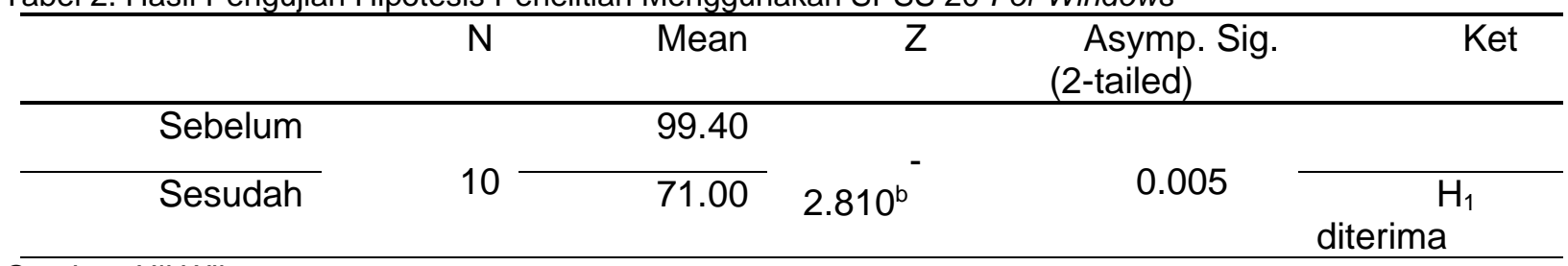

Sumber: Uji Wilcoxon

Berdasarkan hasil penghitungan dengan menggunakan SPSS 20 for windows melalui Wilcoxon Signed Ranks Test, diperoleh hasil skor rata-rata tentang stres belajar mahasiswaUNM. Nilai rata-rata stres belajar mahasiswa UNM setelah diberikan konseling kelompok lebih rendah dibanding sebelum diberikan konseling kelompok. Tingkat stres belajar pada saat pretest berada pada kategori tinggi dengan nilai rata-rata 99.40 dan pada saat posttest Tingkat stres belajar berada pada kategori sedang dengan nilai rata-rata 71.00. Taraf signifikansi yang digunakan dalam uji Wilcoxon signed rank test sebesar $5 \%$ atau 0,05 , dengan nilai signifikan $(\mathrm{P})=$ Asymp Sig< $a=0,05$.

Setelah data mengenai stres belajar mahasiswa UNM dianalisis dengan menggunakan uji Wilcoxon Signed Rank Test maka diperoleh nilai Z yaitu $-2.810^{\mathrm{b}}$ dengan nilai Asymp Sig 0,005. Karena nilai Asymp Sig<a maka hipotesis kerja nihil $\left(\mathrm{H}_{0}\right)$ dari penelitian ini yang menyatakan bahwa "Tidak terdapat perbedaan stres belajar mahasiswa UNM. sebelum dan setelah 
pemberian perlakuan berupa konseling kelompok dengan menggunakan konseling puisi pelipur lara" dinyatakan ditolak. Sehingga hipotesis kerja alternatif $\left(\mathrm{H}_{1}\right)$ yang menyatakan bahwa "terdapat perbedaan stres belajar mahasiswa UNM. sebelum dan setelah pemberian perlakuan berupa konseling kelompok dengan menggunakan konseling puisi pelipur lara" dinyatakan diterima. Dengan demikian dapat disimpulkan bahwa konseling puisi pelipur lara dapat mengurangi stres belajar mahasiswa UNM.

Kesulitan dalam mengerjakan tugas, kurang waktu untuk mengerjakan tugas dan tidak mengerti materi pembelajaran merupakan hal-hal yang berkaitan dengan permasalahan di dalam kegiatan akademik. Hal ini sesuai dengan teori yang menyatakan bahwa penyebab stress mahasiswa yaitu stress akibat akademik, akibat masalah interpersonal, akibat kegiatan pembelajaran, akibat hubungan sosial, akibat dorongan dan keinginan serta akibat aktivitas kelompok (Fink, 2009: Yusiff \& Rahim, 2010). Data di atas mendukung dari apa yang dipaparkan Smith (1993, karakteristik khas dari stres yang dialami anak usia masa awal remaja ini (12-17 tahun) adalah mengalami kesulitan akademik (stres dalam mengelola waktu belajar/strategi belajar dan cemas mengahadapi ujian), konflik dengan teman sebaya, konflik dengan guru, dan konflik dengan orang tua.

Keterbatasan hasil penelitian ini adalah ruang lingkup penelitian adalah mahasiswa yang mengalami stress belajar dalam kategori sangat tinggi yang berjumlah hanya 10 orang. Hasil penelitian ini dapat berbeda apabilan dilakukan dalam setting konseling indivual dengan jumlah sampel yang masuk kategori tinggi. Hasil penelitian ini bisa berubah seiring dengan proses belajar dan karakteristik mahasiswa. Saran penelitian lanjutan adalah teknik ini dapat digunakan untuk untuk masalah-masalah yang serupa seperti kecemasan dan kepercayaan diri.

\section{Simpulan}

Konseling pengungkapan diri melalui puisi pelipur lara dapat mengurangi stress belajar mahasiswa Universitas Negeri Makassar tahun ajaran 2017/2018. Baik dari aspek fisik dan psikis. Temuan penelitian ini memperkuat temuan penelitian sebelumnya tentang teknik konseling behavioral untuk mengurangi stress belajar. Tetapi juga melengkapi karena belum ada peneltian tentang teknik konseling puisi pelipur lara. Temuan ini penelitian ini juga dapat dapat menjadi rekomendasi untuk penelitian selanjutnya melaksnakan teknik konseling dengan menggunakan puisi untuk masalah-masalah yang terkait dengan gejala kecemasan.

\section{Ucapan Terima Kasih}

Ucapan terima kasih kepada mahasiswa,Dosen pada lingkungan Universitas Negeri Makassar atas kerjasamanya dalam penerapan penelitian eksprimen ini sehingga penelitan dapat berjalan dengan lancar.

\section{Daftar Rujukan}

Gainau, Maryam B.. 2005. Pengembangan Inventori Self Disclosure Bagi Siswa Sekolah Menengah Atas di Malang. Tesis. Tidak Diterbitkan. UM Malang.

Greenberg, J. S. 2002. Comprehensive stress management. New York: Mc Grawhill.

Goldman., Cristin. S., Wong., \& Eugene. H. 1997. Stress and the college student. Journal of Education. http://www. findarticles.com. Diakses Tanggal 16 Januari 2007.

Johnson, D.W. (1981). Reaching out. Interpersonal Effectiveness and Self-actualization. Englewood Cliffs: Prentice-Hall.

Mahmud, Alimuddin \& Sunarty, Kustiah.2017. Teknik-teknik Bimbingan dan Konseling. Makassar:Penerbit UNM. 
Ross, S. E., Nielbing, B. C., \& Heckert, T. M. 1999. Sources of stress among college students. College student journal, 33, 3-12.. http://www. findarticles.com. Diakses tanggal 12 Maret 2006.

Smith, J. C. 1993. Understanding stress and coping. New York: MacMillan Publishing Company Lazarus, R. S., \& Folkman, S. 1984. Stress, appraisal and coping. New York: Springer.

Selye, Hans. 1976. The Stress of Life. New York: McGraw Hill.

Sujadi, E. (2019). Penerapan Play Therapy dengan Menggunakan Permainan Tradisional untuk Meningkatkan Keterampilan Sosio Emosional. Jurnal Bimbingan dan Konseling Terapan, 3(1), 14-24. https://doi.org/http://dx.doi.org/10.30598/ibkt.v3i1.892.

Yusoff, M. S. B., \& Rahim, A. F. A. (Eds.). (2010). The medical student stressor questionnaire (MSSQ) manual. Universiti Sains Malaysia.

\section{Competing interests:}

The authors declare that they have no significant competing financial, professional or personal interests that might have influenced the performance or presentation of the work described in this manuscript. 